\title{
Social-Community Involvement in Teacher Training Programs
}

\author{
Nitsa Dori ${ }^{1}$
}

'Head of the Department of Early Childhood, Shaanan Academic College, Haifa, Israel

Email:a.dori@gmail.com

Licensed:

This work is licensed under a Creative Commons Attribution 4.o License.

Keywords:

Social involvement

Teacher training

Education

Volunteering program

Pre-school teachers

Students.

\begin{abstract}
Social involvement in teacher training programs is, in practicality, the very core of preparation for later educational work. Education means an added value beyond transfer of knowledge and endless attempts at nurturing people to treat both themselves and others better; to develop on an individual and social level; to operate with shared values, and share in a human reality broader than individual interests. The encounter with human distress and pain is an inseparable and essential part of every person who is or will be involved in a social or communal role teaching, education, therapy, medicine, or public administration. This encounter creates the motivation, or even obligation, within us, to act to change reality. The goal of this article is to describe a volunteering program that operates to train educators - student pre-school teachers at the Shaanan College, and demonstrate its contribution to the training itself.
\end{abstract}

Funding: This study received no specific financial support.

Competing Interests: The author declares that there are no conflicts of interests regarding the publication of this paper

\section{Literature Review}

Many institutions and thinkers support academic involvement in the community based on Dewey (1916) that emphasizes the reciprocal relationship between democracy and education with learning through action (Benson, Harkavy, \& Puckett, 2000). Social-community involvement has become part of academia worldwide. The global changes in economics and society have also impacted the education system and higher education. Volansky (2005) describes how, since the end of the twentieth century, these processes have forced academic institutions to leave the tranquility of pure research in which they reveled. The changes in capitalism and the resulting competitiveness also challenge them anew to justify their existence, in such forms as increasing accessibility to higher education for population groups that could not access it in the past, and translating the freedom of academia into social responsibility.

The sociologist and philosopher, Bauman (2000) describes our age using the metaphor of liquid modernity. If modernity was once solid, certain, and known, during the postmodern period the social institutions around us are melting and becoming liquid. These include the institution of family, the labor market, the community, and of course educational systems. Beck (2002) called this phenomenon the "risk society" and referred to the social repercussions of the increasing rate of change on how life is experienced in our times. The task that faces academia in this situation is not just to train students, but also prepare critical, active, and entrepreneurial citizens who can interpret, and operate within, reality (Haisraeli, 2018).

The recently published Education in an Age of Uncertainty (Weinberger, 2016) proposes that teachers use the qualitative research method and interpretive approach as tools to help them learn about the processes of change taking place before their eyes in their classrooms and surroundings. Almog and Almog (2016) from the University of Haifa comment that Generation Y is now reaching the classrooms. Young people today have significantly different assumptions regarding life than earlier generations, brought about by psychological and sociological reasons outside the scope of this article. Today's students are searching less for theoretical knowledge and more for practical knowledge, less general background and more practical training. Less "talk" and more "experiencing". One reason for the ground breaking development of the colleges and their advantage over universities in recruiting students is connected with their ability to adapt themselves to this expectation, and provide their graduates with a variety of practical tools (Haisraeli, 2018). Of course, this article does not 
come to suggest excluding theory, but it must certainly be taught differently, in a way that incorporates the practical side.

Proposals to strengthen studies by including community involvement arouse great interest (KalekinFishman, 2018). The global trend can be seen in concepts such as CLB (Community Based Learning) or SL (Service Learning) (Thomson, Smith-Tolken, Naidoo, \& Bringle, 2010). CLB focuses on a mixed academic faculty, community organizations, and students who create partnerships, with the aim of actively advancing both academic achievements and community goals (Dallimore, Rochefort, \& Simonelli, 2010). The main characteristic of these trends is the pedagogic strategy targeted at integrating students' academic study with community or social involvement; it is assumed that all-inclusive involvement (including that of the teaching faculty) and the common interest of campus and community, will be able to produce both the necessary "depth" for academic learning "connected to reality" as well as the possibility of creating a positive social-community change (Frank \& Sieh, 2016). Integrating students in communal enterprises can accustom them to social participation and consideration for others - a possibly essential component in preparation for adult citizenship (Hart, 2008). If teachers are expected to guide students in community activities, then it is clearly desirable that student teachers be involved in social-community activities (Kalekin-Fishman, 2018). Long-term studies that followed thousands of students committed to community activities showed that courses that combine academic knowledge and experience in the community increase student motivation to continue on to advanced degrees, and also develop their commitment to pluralistic philosophies in the short term too (Astin, 1999; Astin \& Sax, 1998; Astin, Vogelgesang, Ikeda, \& Yee, 2000).

Studies also indicate a positive correlation between students' social involvement while studying and their commitment to active involvement in action for social justice throughout their lives (Maruyama, Furco, \& Song, 2017). Social involvement enables students to become familiar with excluded population sectors who they would not have got to known without these activities (Beaumont, Colby, Ehrlich, \& Torney-Purta, 2006).

Campus-community partnerships seek to demolish academia's walls of seclusion around its ivory tower, and connect students and faculty to the communities around them (Golan, Orr, \& Rosenfeld, 2018). These partnerships help to tear down the barriers between the social groups to which most of the lecturers and many students belong, and excluded social groups, most of whose members are not involved in academia.

The need to make higher education more accessible to the groups which are poorly represented there, was born together with the need to promote active involvement of academia in the community (Trajtenberg, 2013). The partnerships help these social groups meet and create social solidarity, familiarity, and a common struggle for social change. Campus-community partnerships contribute to the understanding that knowledge does not exist only in academia, and that there is great value to learning from all the participants, particularly those from the excluded communities, since their significant and important knowledge is usually also excluded from academic institutions. Many partnerships aspire to promote as equal, symmetric, and reciprocal relations as possible among the partners, despite the substantial difficulties that may be involved. Moreover, many campus-community initiatives are characterized by interdisciplinary learning and challenge the disconnection between different knowledge areas, such as that between classroom learning, academic research, and social action in the community (Golan et al., 2018).

The emphasis on democratic values helps transform students from volunteers providing a service to the community into activists for social justice, and the higher education institutions into agents for social change (Marullo \& Edwards, 2000). Social involvement evokes personal changes in the lives of the individual and community, that contribute to positive self-image, a feeling of independence and control, and a high level of decision-making ability and self-esteem when making those decisions (Fisher, 1999; Peleg, 2000; Sadan, 1997). The sense of ability to help others and devote time to realize important values acts to intensify the volunteer's awareness and personal identity, and strengthens his self-image and motivation (Johnson, Beebe, Mortimer, \& Snyder, 1998).

In addition, experiences of social activism are likely to serve as an infrastructure for effective pedagogic access (Kalekin-Fishman, 2018). In unexpected situations occurring in the real world, students will frequently acquire skills for cooperation in multi-age grouping. The experiences often increase sensitivity to collective problems and the ways in which the participation of citizens contributes to improving social and political situations. Volunteers do not just invest their efforts and give, but are also positively influenced, since they themselves learn to respect others, experience great satisfaction after helping others, and are strengthened and supported in decision making and nurturing mutual responsibility (Hadar, 2010). During recent years, most of the higher education institutions in Israel have developed programs for student involvement in the community and experiencing the meeting point between theory and practice. This development is part of an international trend to reinforce the social involvement of higher education institutions. Over the past decade, the higher education system in Israel has been investing resources in developing programs that integrate academic knowledge with social involvement (Golan et al., 2018).

Even though the volunteer rate in Israel is low relative to other Western countries (Bar \& Dror, 2015) over $70 \%$ of all volunteers are students, for three hours weekly (Haski-Leventhal, Handy, \& Cnaan, 2009). 


\section{Research Method}

The study was qualitative. The students' volunteering was observed and the students were interviewed, to examine their experiences during the study.

\subsection{Study Population}

Female students of early childhood education at the Shaanan Academic Religious Teachers' College in Haifa, Israel.

\subsection{Research Goal}

To examine the value of volunteering among the students, and whether their patterns of behavior had changed in this regard. Volunteering was also examined as a social lever for the integration of various groups in Israeli society.

\subsection{Goals of the Actual Project}

- To meet a special-needs population outside the college, to both contribute to, and benefit from.

- To intensify the students' awareness of communal challenges and their ability to contribute to different and varied communities.

- To get to know the members of the community, the place, and the professional staff in the places where they volunteered.

- To implement the teaching methods learned in the college by planning and leading the activities, with special attention paid to the special needs of each community.

These goals are an expression of the importance the college places on campus-community relations and student involvement in community life (Golan, Orr, \& Rosenfeld, 2017).

\section{Findings and Discussion}

If volunteering for the community is seen as a teaching model, then the community where the student carries out their social involvement activities parallels the classroom or preschool where she will teach (Haisraeli, 2018). This is a venue for learning about operating in uncertain conditions, and adopting an attitude of wanting to learning - rather than being fearful. Of watching and not marking, or as Aloni (2014) coined it, "a humanistic, democratic, and participatory approach". The findings are divided into three. The first part discusses the volunteering experience with the elderly, children from a different cultural group, and new immigrant children; the second discusses the students' expectations before, during, and after the project. The third section focuses on how they changed as a result of volunteering. All students interviewed described an exciting experience.

It says in the Ethics of the Fathers (4:2): "the reward for a good deed is [another] good deed". Rabbi Ovadia [Yosef] explained that the reward for a good deed is the good deed itself. That the good deed and the joy it brings is in itself part of the reward. And I feel that giving to the needy has made my life more significant, brought me incredible satisfaction, and imparted me with a feeling of joy, and "it's a great good deed to always be happy". (Tali, Early Childhood Education, $4^{\text {th }}$ year student)

Tali describe volunteering as particularly emotional. She sees it as an exceptional goal that fills the volunteer with a sense of satisfaction. This feeling was especially strong after she had succeeded in cheering up an elderly woman. The formal pedagogic interest for which she had come to the college changed, and the meetings with needy populations turned into encounters full of love and a sense of belonging to the places she visited.

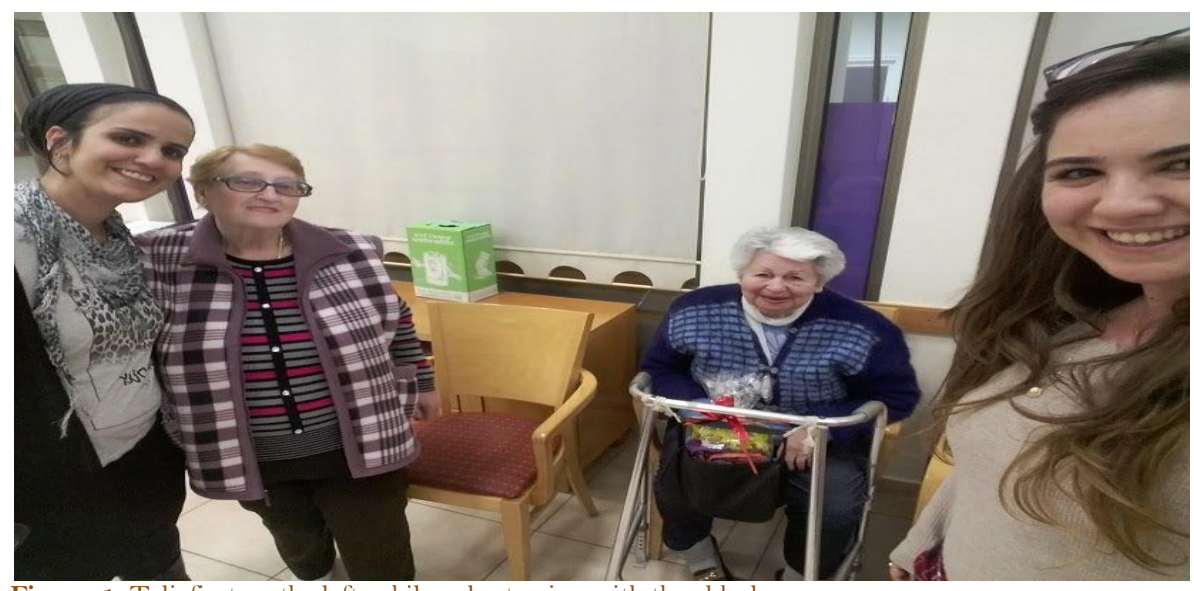

Figure-1. Tali, first on the left, while volunteering with the elderly. 


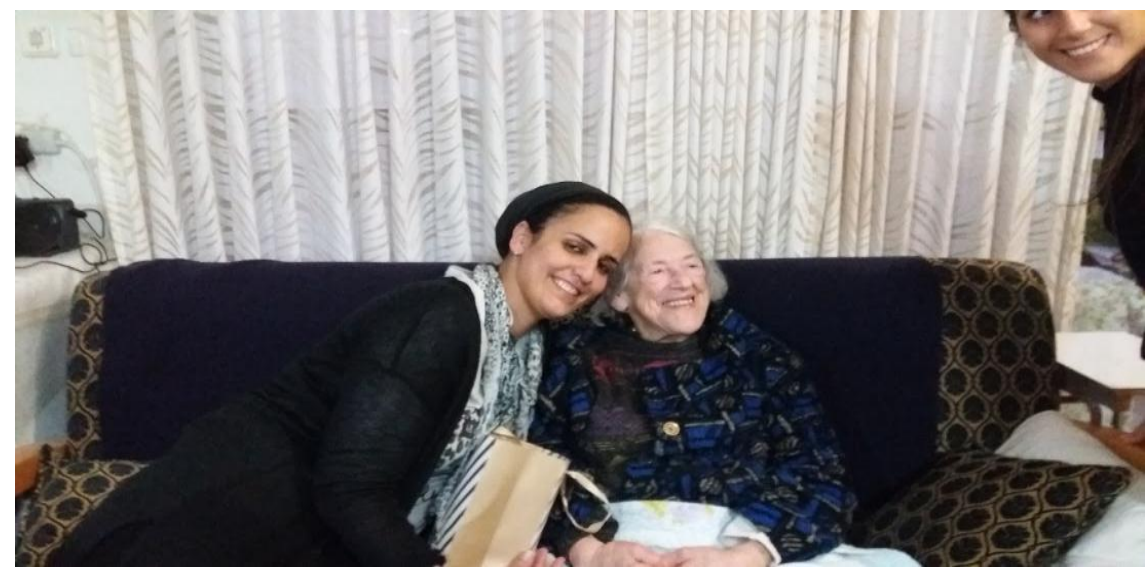

Figure-2. Tali with one of the older women

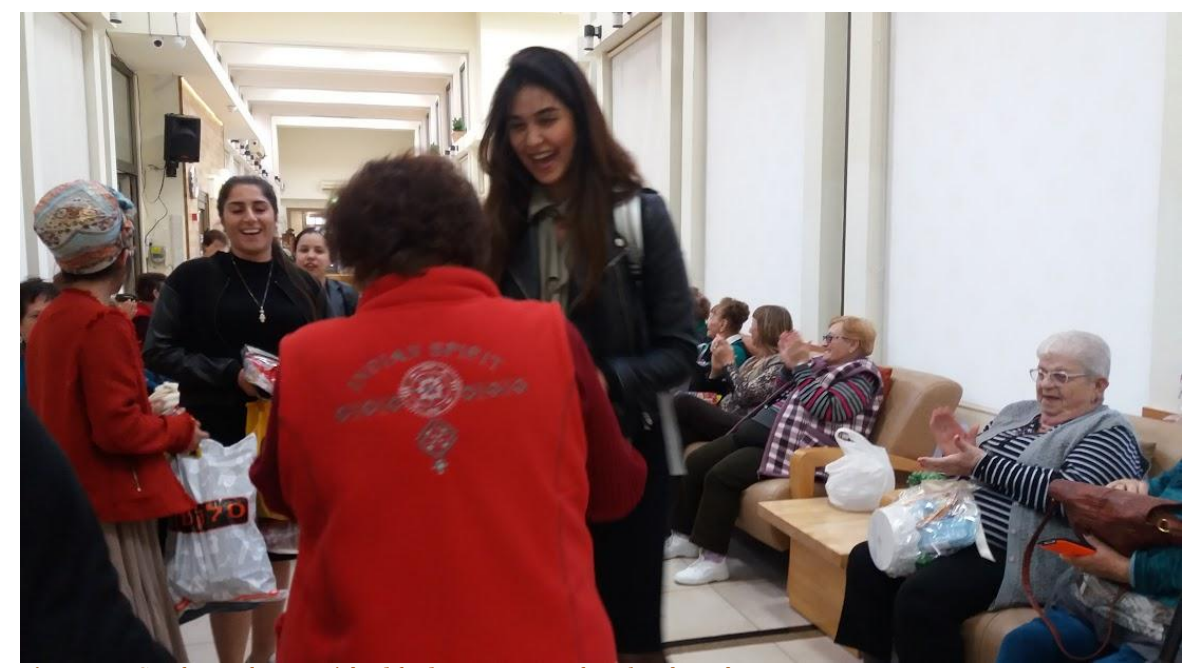

Figure-3. Students dance with elderly women and make them happy.

All my classmates went on the bus to the soup kitchen to pack meals for needy families. There wasn't enough room on the bus, and I made a quick decision to get on the other one, without knowing where it was going. The bus began to move and I asked my friends where we were going. They told me we were going to cheer up residents with special needs at the Kassler Home hostel in Haifa. I tensed up and I was sorry I had got onto that bus. I had been nervous of meeting people with special needs for many years. I had even recoiled from them. I started feeling really bad about it, and so I chose to stay outside and not go into the dancing that the girls arranged with the residents. I had really mixed feelings. I knew it was a day that I was supposed to give of myself voluntarily, without thinking of myself. A day without ego, just true giving. A day on which I should devote what I did to others - even someone who I didn't know. That a quick smile and a pleasant conversation would make their day. But I also felt there was a barrier. I was scared to go inside and meet them. How could it be that a healthy young woman of twenty-three was so frightened? While I was sitting outside, a man of about forty approached me and sat beside me. He cut off the thoughts racing around my head. He looked at me and smiled. A giant smile. He asked me, 'What's your name? Why didn't you go inside?' He had mild retardation and the joy on his face amazed me. I told him that I'd go inside soon... and he said, 'I know! You're afraid of them, of my friends. Don't worry, I won't tell anyone. I know what you're feeling. You should know that I was also bothered when I came here. But now they are my family. They're my best friends.' I suddenly felt I had the courage, thanks to him, and we went inside. It was an amazing feeling. I really experienced it deeply. It took me several days to digest the range of feelings I experienced that day. Tension, frustration, fear, and real joy, and the main thing was that I saw things in the right proportions. I learned to value the little things in life: standing up, walking, speaking. But more than anything else - I felt satisfaction that I had given that day and how I had overcome the fear. (Moriel) 
Moriel opens up and relates how an encounter with one of the hostel residents who sat down next to her helped her overcome both her anxiety and the internal embarrassment regarding it, about meeting with people with special needs. Moriel's conflict found her "thrown straight in at the deep end", face to face with the thing she was so afraid of. When Moriel will be a preschool teacher, and will need to integrate children with special needs in her preschool, she will no longer recoil in fear. This served as a kind of test for her entering an inclusive society that accepts every person by virtue of their being a human being. Moriel needed such an experience to strengthen herself regarding her attitude to those with special needs.

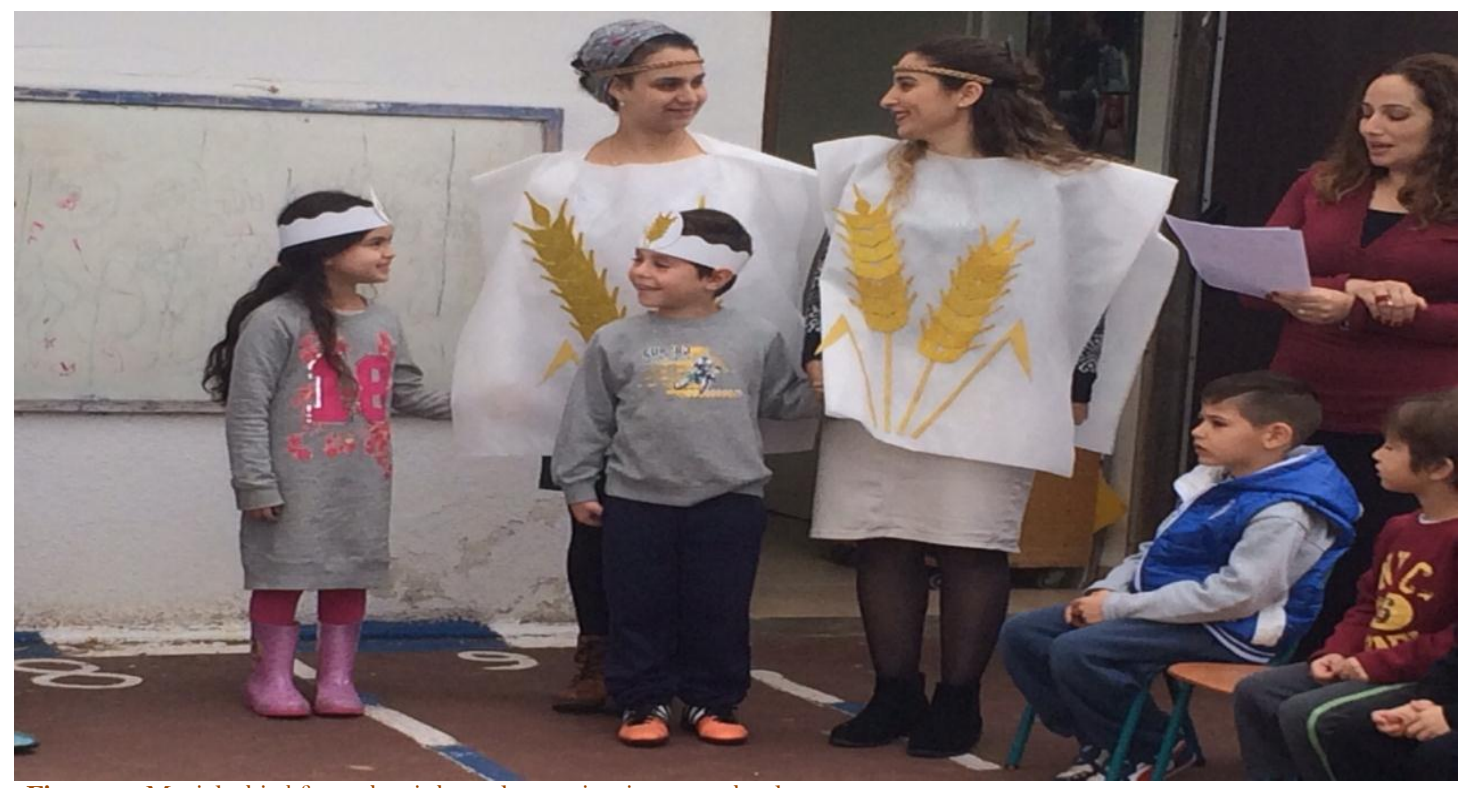

Figure-4. Moriel, third from the right, volunteering in a preschool.

Roni relates, "The feeling that you are helping, and what you are doing will help someone, is good, but in this case, preparing food for needy people, I felt that what I was doing wasn't enough.”

Volunteering gave me a sense of satisfaction and a feeling that we need to say 'thank you' for what we have. Nothing is self-understood, there are people who don't have [what they need] and aren't able to buy. That is a difficult feeling. The little I gave won't help them that much. Perhaps a little. This was an experience that will stay etched on my memory for a long time. (Naima)

Roni and Naima express true feelings of compassion. They feel the help they offer is just a drop in the ocean. Will this bring them to continue volunteering outside the college framework too? It's hard to say for certain, but undoubtedly Roni and Naima have begun to be aware of other people's suffering, and a desire has been aroused within them to lessen this suffering. Perhaps at one of the other junctions in their lives they will remember the volunteering experience at the college as a formative experience and operate again in their personal-private or public framework as preschool teachers to encourage themselves and others to volunteer with varied population sectors, as emphasized in what students Avital and Bat Chen say:

We need to volunteer regularly as a significant part of our being people with values and ethics, who give of themselves. Being exposed to volunteering at the college provided us with the incentive and inspiration to continue spreading the good we have inside us. (Avital) After volunteering in an old age home through the college, I decided to continue volunteering with the elderly where I lived. Every Thursday, I began to visit five old people who live near me, and buy them flowers for the Sabbath. I discovered that I felt greatly fulfilled and I would return home joyously. When I was given my own preschool during my fourth internship year at the college, it was clear to me that I was going to adopt these elderly people with the children in my preschool. Now we visit them together, invite them to events, ceremonies, and festivities in the preschool, sing and celebrate with them, and make sure to give them a modest gift every festival (I consider children's drawings a gift too). Undoubtedly, if I wouldn't have been exposed to volunteering with the elderly at the college, I wouldn't have done this. I want to say thank you and how much I value it. (Bat Chen)

Bat Chen seemingly adopted the practical approach to volunteering that she had experienced at the college, more than anyone else. She has also continued volunteering with the preschool children, who she began working with during her internship, fourth, year at the college. Clearly the preschool children's relationship with the elderly people who live near the preschool also strengthens their intergenerational connection with their own grandparents, and thus both sides gain: the old people have their loneliness 
alleviated by their warm connection with the children, and the children enjoy a different kind of relationship, one of giving (Bat Chen emphasizes that their drawings are also a kind of giving), concern, and caring for the elderly.

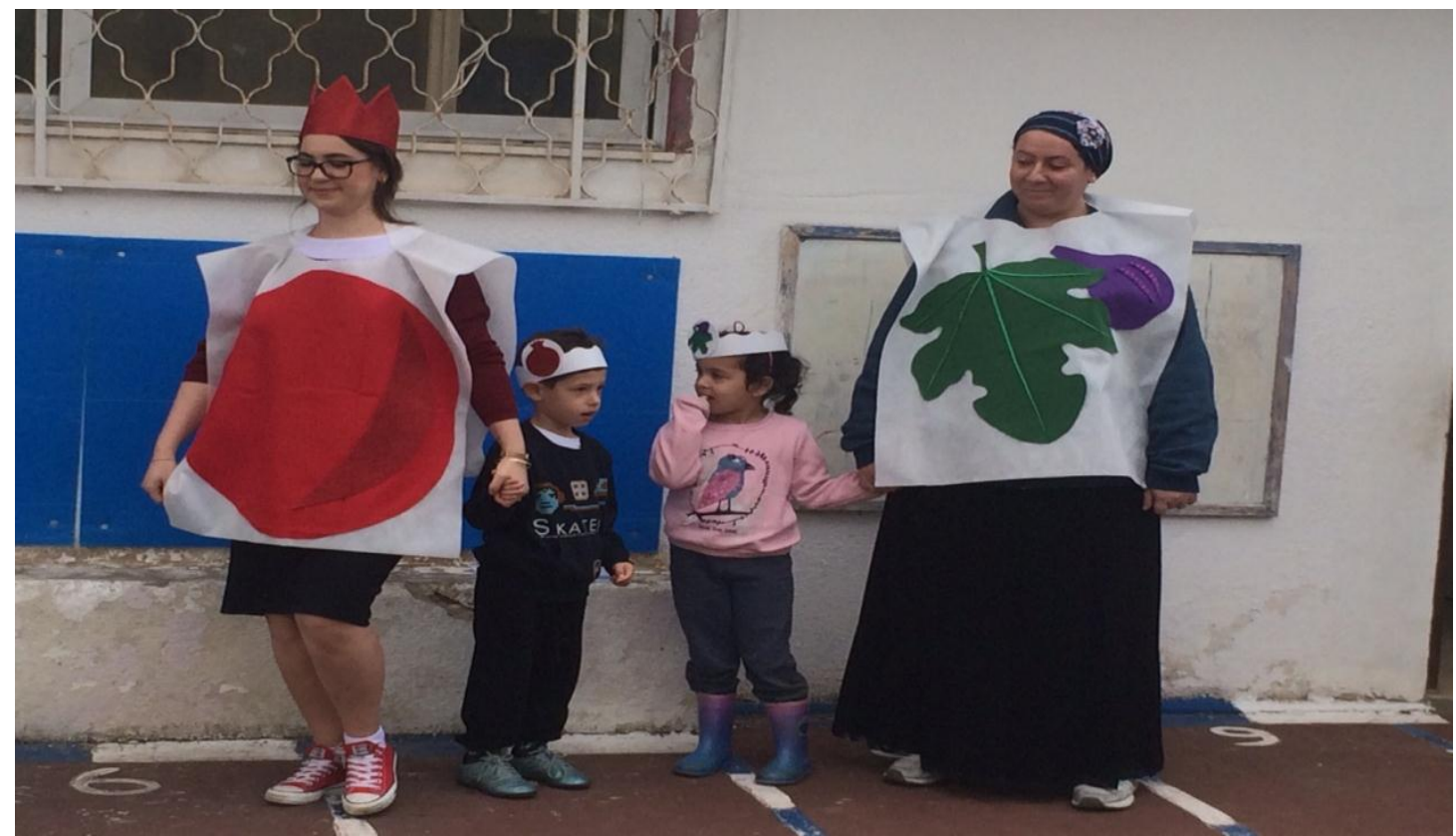

Figure-5. Bat Chen, on the left, volunteering in the preschool.

I volunteered to distribute mishlohei manot [gifts of food sent on the Jewish festival of Purim] to old people in an old age home. I met a childless woman who was totally alone. When she saw we had come into the room she burst into tears. I hugged her and I also cried. I felt I had done something significant. She was delighted. Because of me, someone who was lonely, was happy. She felt that finally she was important to someone in the world. I encouraged her and since she was sick, I wished her a speedy recovery. That was a very meaningful day in my life. It's not every day that I can do such good things. I felt that the good deed had brought me closer to the Creator. I felt elated. (Galia)
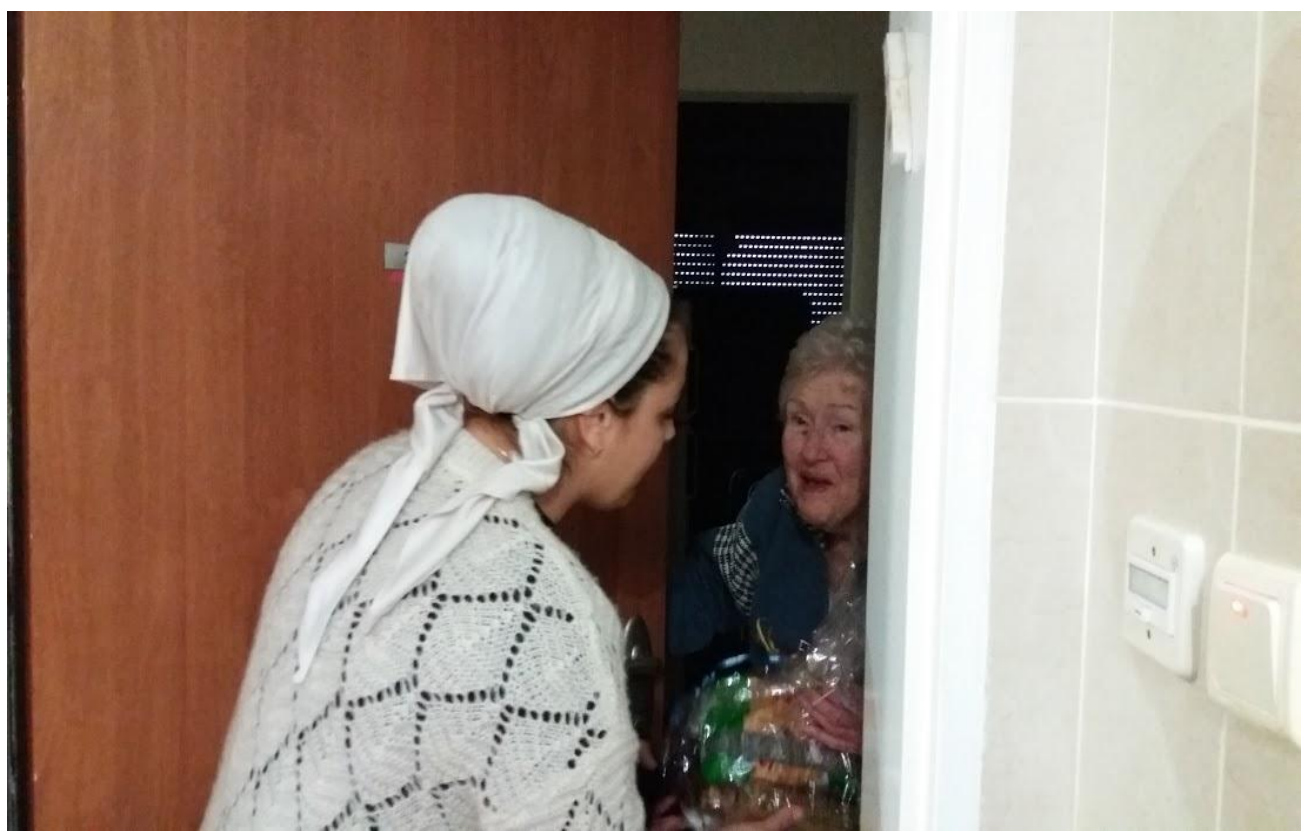

Figure-6. Galia distributing mishlohei manot to the elderly 


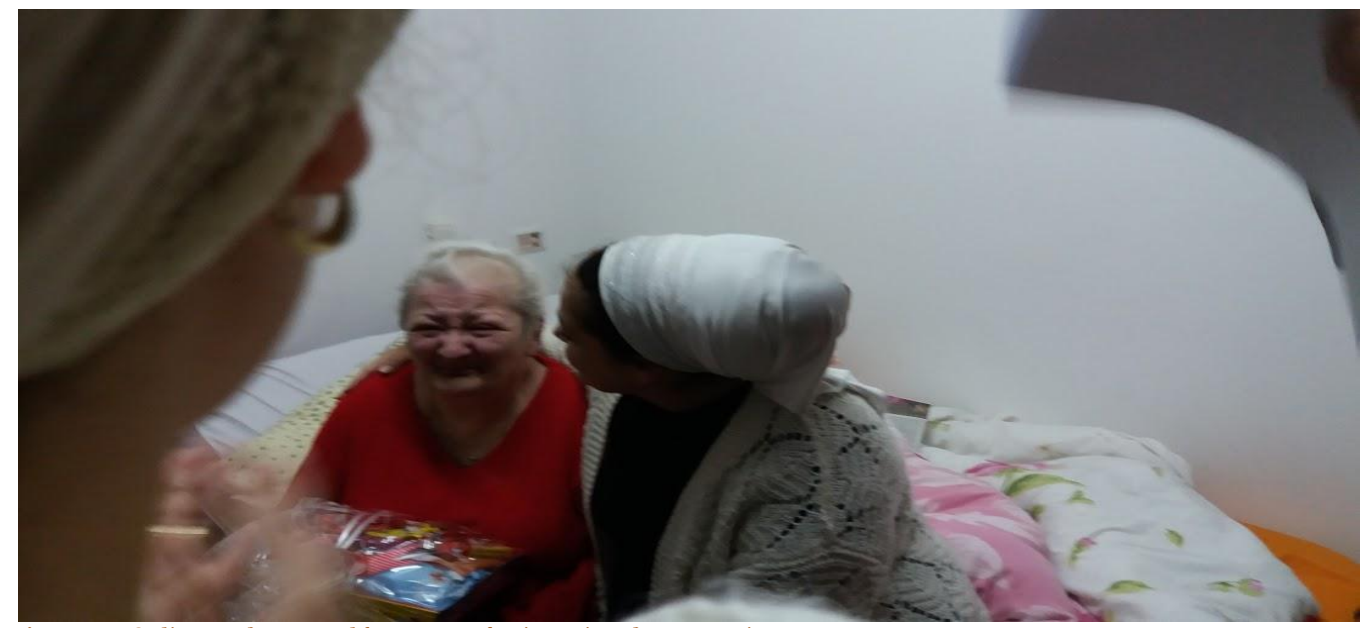

Figure-7. Galia comforts an old woman who is crying from emotion.

Galia raises a personal aspect in what she feels. She says that the volunteering helped her become closer to the Creator. In other words, the volunteering was a spiritual experience for her, making her feel she had become a better and more ethical person, concerned about those around her. In the picture, Galia is seen placing her hand on an old woman's shoulder, sitting very close to her, looking at the woman's face, and radiating empathy.

Some of the students were nervous of meeting the old people, due to the wide age gap and the fear they would not understand one another. The meetings presented the students with challenges, and encouraged them to continue. Most of the students reported becoming closer to their roots through the elderly people's stories that helped them connect with their own grandparents.

I volunteered to package food for the needy. The work itself was in a small, crowded, and suffocating place. I initially felt bad. I couldn't understand how people could work like that. But I soon changed. I thought of those families who really needed the food I was packing, and at that moment I didn't care about the crowding, the lack of air, the intense heat... I just thought about the families and concentrated on packing. I wanted them to receive the food in a clean and dignified manner, just like I would want to receive it, that it would be packed lovingly. When we came back to the college after the packaging, I felt wonderful. I felt I had participated in something important for others, who need our help. I imagined the families who would receive the cartons, and it made me so happy. (Geut)

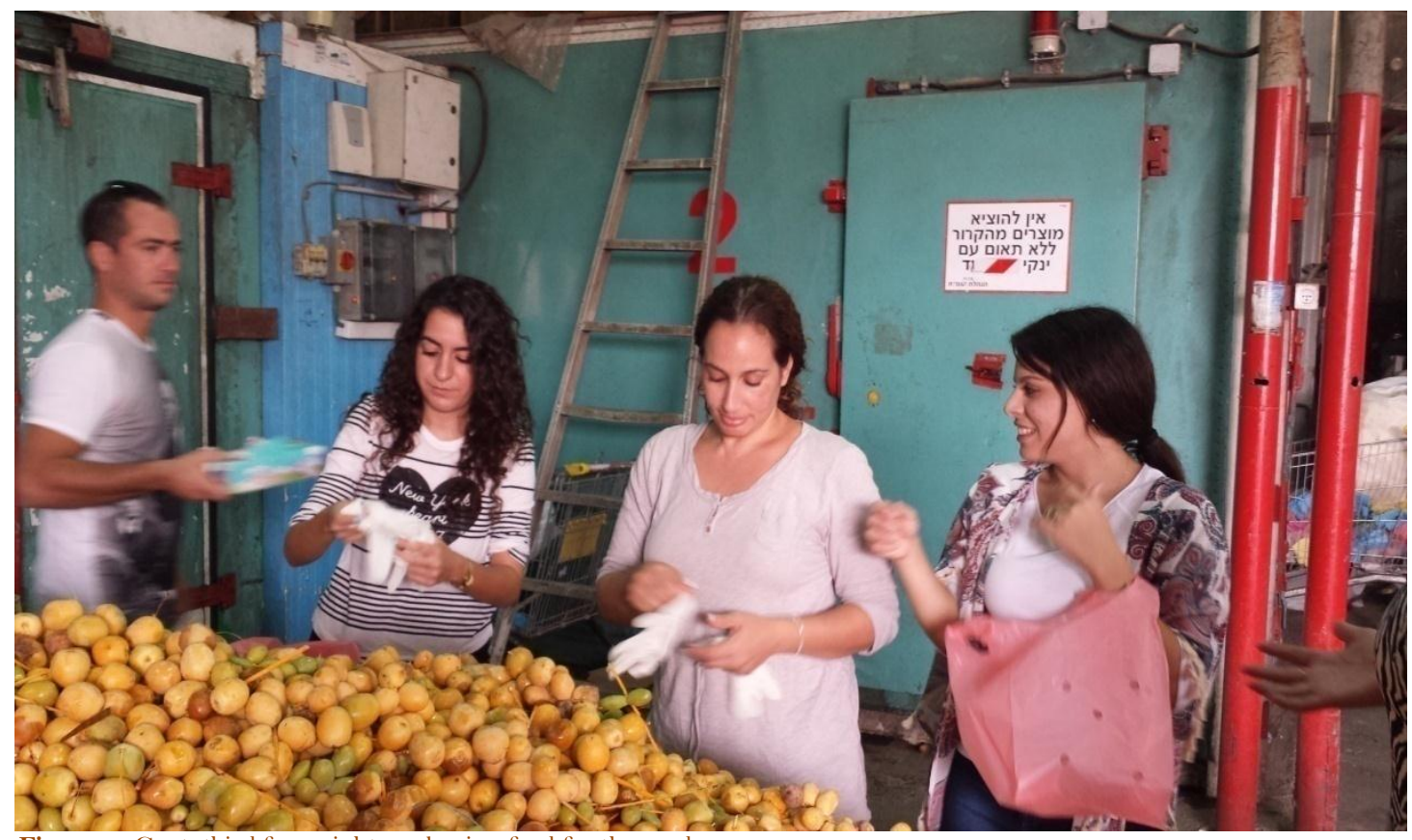

Figure-8. Geut, third from right, packaging food for the needy.

Geut describes how she overcame her initial feeling of disgust with the location and setting when she imagined the families waiting for food. She used her imagination to get over her feelings of disgust, aversion, 
and discomfort, and create an imaginary picture in which the families receive the food that she packaged with joy. This image helped her complete her volunteering task, and despite the physical distance from the people who needed her, she felt that she had brought them the food herself.

When we came to package food for needy families, it was really hot and there was a smell of rotten fruit and vegetables, and lots of flies. I felt I had missed the point of why I had come. I was disgusted with how the foodstuffs were set out, the lack of hygiene, and I felt sorry for the people who were supposed to get this food. When I left, I admired the girls who were prepared to clean, sort, and wash [the food]. My feelings of repulsion won. I simply couldn't. (Sharon)

Sharon describes her feelings that led her to miss out on volunteering to pack food for the needy, with openness and honesty. In a picture of a different volunteering situation, that included putting on a play for children, Sharon appears to be enjoying herself very much, smiling, clapping, and even performing as an actress. The fact that the students can choose from a wide range of places and varied activities, gives them the feeling that if they do not enjoy one position they can feel completely differently about another place. At the same time, we make it clear to them that they need to grapple specifically with their aversion to the places where they find it difficult, and try again. Because in real life, outside the college that makes sure they have a range of volunteer opportunities, they will find themselves in situations when they won't be able to choose. The reality will make them, sometimes, struggle with the same people and places from which they were initially repulsed.

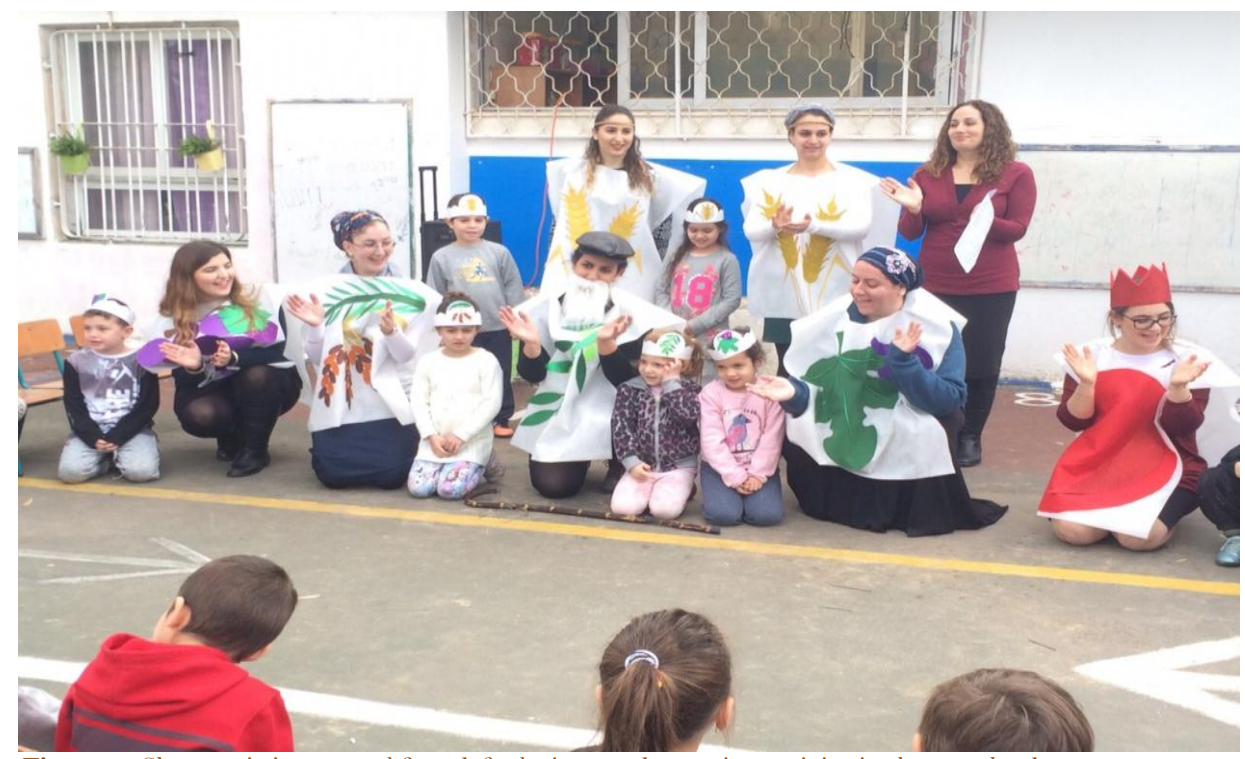

Figure-9. Sharon, sitting second from left, during a volunteering activity in the preschool.

Two students reported continuing volunteering in their own communities after having been exposed to the issue at the college, in a different field to that which the college offered:

A friend who I had lost contact with in recent years underwent difficult and complicated surgery on one of her limbs at the beginning of the year, which led to terrible pain while recuperating and being totally unable to function in her home and with her family. When I went to see her and saw how helpless she was, I simply stayed there for three weeks to help her run her home, look after her children, and mostly to encourage her when she was depressed and in pain. I felt a kind of mission and a real desire to help her and see her improve. My belief in God had wavered a little over the past two years, but after helping her, she significantly improved as did my belief in the power of miracles. (A student who wishes to remain anonymous).

This student describes a situation in which she thought to visit a friend who was recovering from surgery, but "the visit" turned into a three-week long volunteering project. On the spur of the moment, seeing her friend's situation, the single student left her home and moved into the house of her friend - who was married and had children - and helped her run her home and care for her children. Perhaps this student would have done the same thing with humane motives, even without seeing the contribution made to weak populations during volunteering at college, but undoubtedly the awareness regarding the contribution of volunteering, that she received during her first years in the college, also helped her courageous and commendable decision in light of her friend's situation. Beyond the feeling of satisfaction from volunteering, it strengthened the relationship between the two friends which had waned. 
There's a single mother with three children in my neighborhood. We got together, a few families, mostly mothers, and decided to help her look after her children once a week, and each family looks after one child for about a month. The other two children are with other families. The whole community made an effort so that she could successfully complete her studies. I am excited to be part of this project and part of this community that took on itself to be friends and give help to others. For the last charity fair we held, I volunteered to prepare couscous (a large amount, around $4 \mathrm{~kg}$.) and make a booth where I sold it all for charity. On the day of the fair, I felt incredible, like I was floating on air. Everyone was pleased for me and complimented me on how delicious the couscous was. I felt I gained tremendously. (Tali)

Tali narrates two stories of volunteering at home. Looking after the children of a single mother so that she could continue studying (as a married student with children, Tali knows how hard it is to study without help and support), and volunteering at a charity fair to prepare food for sale with the profits donated to the needy. Tali prepared four kilograms of couscous, which means a lot of work. Although the cost of four kilograms of semolina is low, preparing the couscous takes much time and effort. Tali ends by saying, "I gained tremendously". She did not earn money, she spent time, and worked hard to prepare the food, but still writes that she had gained. Since she did not explain what she had gained, it can be assumed that her tremendous gain was the feeling of satisfaction and joy in giving.

What is common to all volunteering work is that people donate their time regularly and consistently to work that is of value to society (Gidron, 1983). The basis of every volunteering activity is doing something without being forced. Unlike a one-time volunteer (such as someone helping a child cross the road), someone who continues volunteering in the same place over time is not doing anyone a favor. They return to their familiar place of volunteering and fulfill their duty, as is expected of them, apparently because the work interests and attracts them in some way (Gidron, 1977). The literature about motivation for volunteering is based on a pioneering study by Sills (1957) in which he distinguished between two volunteer motives: unselfish motives directed at others, and the volunteer's own motives. Current literature also notes that volunteering is not wholly altruistic, and contains a component of personal benefit, or satisfies the volunteer's personal desires and his wish to help others (Gidron, 1983). For example, a study about community activity found that people are involved not only due to value-based philosophies, but also because of a personal need to belong to and connect with someone (Monnickendam-Givon \& Blit-Cohen, 2012).

The literature about volunteerism usually argues that only volunteers who feel satisfaction from their activity will continue. However, it is not clear what this satisfaction is. What components of the position bring the volunteer pleasure? Perhaps the position itself? The type of activity? Or perhaps the status that accompanies the position? Volunteer satisfaction emanates from two factors of the activity - the work itself and its achievements, and two factors of the activity framework - comfort and a lack of frustration (Gidron, 1983). Volunteers are satisfied if the activities are challenging and interesting, make use of their talents, allow independence, and demand responsibility. There is also satisfaction when the people benefitting from their work advance, the position is in a convenient time and place, and there are no other organizational problems that interfere with their work.

Volunteering contributes greatly to self-perception, increasing belief in each student's ability in their own social influence, and their sense of importance simply as a human being. The volunteering setting allowed the students simple and direct contact together with their friends, and therefore conveyed a personal benefit that cannot be measured in material terms. This feeling is strengthened in theory by the philosophies of Bandura (1993) and Bandura, Barbaranelli, Caprara, and Pastorelli (1996) and other studies that emphasize the experience of partnership as a significant component in volunteering (Garst, Scheider, \& Baker, 2001).

\section{Summary}

The findings clearly show how the social involvement sessions left the students with the feeling of having experienced something intense. They thus discovered individual abilities within themselves, such as inclusion, empathy, giving, and tolerance. As well as benefiting others, their feelings of success and belief in themselves and their strengths clearly also created change within them. Thus their professional identity was also strengthened. The feedback testifies to internalization of the processes they experienced. These experiences contributed to the student teachers, both as people and as future professionals, and are expected to also empower them when they teach in the education system. The study shows that awareness of social change must be increased by training teachers and students who will lead it, in order to create a more equal and just society. Examining the limits of our inclusion of other people's pain and suffering help form an ethical position that is committed to action (Lampert, 2018). There needs to be movement to and from the classroom outside and back again (Haisraeli, 2018) because awareness is not sufficiently developed in the classroom which does not include all the necessary skills and tools. But merely leaving the classroom is also not enough. This to and fro movement will develop awareness, and lead to social and educational action and activism (Haisraeli, 2018). An inclusive look means greater professionalism, and significantly contributes to the training, since it enables the teacher to see things through the eyes of the other person with difficulties. This is the basis for structuring 
the image of a social mission. Even when the concrete action does not achieve the goal of "wiping out the suffering" (and it almost never does), it still offers value, significance, and recognition to the person who suffers and to those working to lessen that suffering.

The future preschool teachers and teachers will work in reflective systems. It is hard to speak with students about commitment, values, social contributions, or belonging, without such talk having personal relevance. Meaning, there is great potential for social humanitarian activism as part of teacher training: it can help population sectors in distress in general and children in particular; promote and intensify the feelings of self-worth and self-efficacy of those studying to be teachers; enable students to be better teachers, and impart a training institution with double prestige - as both a leader in pedagogic innovation for higher education and a place that advances worthy social missions. A personal commitment, without pay, scholarship, or other material gain, brought about a change in social and personal philosophies among the students, and this model can also be implemented in other countries and societies. Students with experience in a social organization who were exposed to weak and excluded populations, as well as school or preschool teaching experience, will better understand the student populations they will teach in the future. Such students will not be satisfied with their students' academic achievements, but also ask themselves - what is the family's socioeconomic background? What neighborhood do my students come from? What is the rest of their day like after they finish school? And how do all these things influence my ability as a teacher or preschool teacher to help them succeed in their studies? This social involvement invites student teachers to challenging meetings and to address complex systems, at the border between academia, society, and community. The session offers alternative, democratic approaches and partnerships within the community. Regarding the question of how much growth potential there is for each party involved in such activity - the institution, student, and community - and what contribution they make, the best answer is in the action. Such action breaks down the walls of the college, connects with various bodies in the community, is supported by local agents of change, and its very essence is the implementation of the ideas learned by students in the classroom. And the more they leave that classroom to do things, the more its conscious and social development and presence will intensify on campus and in the community.

\section{References}

Almog, T., \& Almog, O. (2016). Generation Y. As if there is no tomorrow. Ben Shemen: Modan.

Aloni, N. (2014). Interdisciplinary thought in humanistic education: Lectures and speeches from the 8th annual conference on progressive education (pp. 7-9). Tel Aviv: Kibbutzim College of Education.

Astin, A. W. (1999). Student involvement: A developmental theory for higher education. Journal of College Student Involvement, 4O(5), 518-529.

Astin, A. W., \& Sax, L. J. (1998). How undergraduates are affected by service participation. The Journal of College Student Development, 39(3), 251-263.

Astin, A. W., Vogelgesang, L. J., Ikeda, E. K., \& Yee, J. A. (2000). How service learning affects students. Los Angeles: Higher Education Research Institute.

Bandura, A. (1993). Perceived self-efficacy in cognitive development and functioning. Educational Psychologist, 28(2), 117148 .

Bandura, A., Barbaranelli, C., Caprara, G. V., \& Pastorelli, C. (1996). Multifaceted impact of self-efficacy beliefs on academic functioning. Child Development, 67(3), 1206-1222.

Bar, R., \& Dror, N. (2015). Theory and practice: The multi-sector volunteerism enterprise for promoting volunteering and social participation in the light of the collective impact perspective. Etz Hasadeh, 15, 89-109.

Bauman, Z. (2000). Liquid modernity. Cambridge: Polity Press.

Beaumont, E., Colby, A., Ehrlich, T., \& Torney-Purta, J. (2006). Promoting political competence and engagement in college students: An empirical study. Journal of Political Science Education(2), 249-270. Available at: http://dx.doi.org/10.1080/15512160600840467.

Beck, U. (2002). Cosmopolitanism: A critical theory for the twenty-first century. Tel Aviv: Hakibbutz Hameuhad.

Benson, L., Harkavy, I., \& Puckett, J. (2000). An implementation revolution as a strategy for fulfilling the promise of university-community partnerships: Penn-West Philadelphia as an experiment in progress. Nonprofit and Voluntary Sector Quarterly, 29(1), 24-45. Available at: https://doi.org/10.1177/0899764000291003.

Dallimore, E., Rochefort, D. A., \& Simonelli, K. (2010). Community-based learning and research. New Directions for Teaching and Learning, 124, 15-22. Available at: https://doi.org/10.1002/tl.416.

Dewey, J. (1916). Democracy and education: An introduction to the philosophy of education. New York: Macmillan.

Fisher, A. (1999). The connection between a feeling of empowerment and volunteering and community involvement among teenagers (Unpublished Master's Thesis. Bar-Ilan University, Ramat Gan, Israel.

Frank, I. A., \& Sieh, L. (2016). Multiversity of the twenty-first century - Examining opportunities for integrating community engagement in planning curricula. Planning Practice $\&$ Research, 31(5), 513-532. Available at: http://dx.doi.org/10.1080/02697459.2016.1180573.

Garst, B., Scheider, I., \& Baker, D. (2001). Outdoor adventure program participation impacts on adolescent self-perception. The Journal of Experiential Education, 24(1), 41-49.

Gidron, B. (1977). Rewards from volunteer work. Bitachon Sotziali, 14(15), 51-63.

Gidron, B. (1983). Volunteers' satisfaction from their work. Chevra Verevacha, 5(3), 259-270.

Golan, D., Orr, Z., \& Rosenfeld, J. (2017). Bridges of knowledge: Campus-community partnerships in Israel. Tel Aviv: Mofet. 
Golan, D., Orr, Z., \& Rosenfeld, J. (2018). The social involvement of students in academia-community partnerships. Bita'on Machon Mofet(61), 8-13.

Hadar, L. (2010). Volunteering as a tool for empowering at-risk youth. Minituk Leshiluv(16), 43-60.

Haisraeli, A. (2018). Ten years of integrating social involvement in compulsory courses in the Kibbutzim College of Education: Learning activism in practice. Bita'on Machon Mofet, 61, 35-38.

Hart, R. (2008). Stepping back from 'the ladder': Reflections on a model of participatory work with children. In A. Reid, B. B. Jensen, J. Nikel, \& V. Simovska (Eds.), Participation and learning: Perspectives on education and the environment, health and sustainability (pp. 19-31). Berlin: Springer.

Haski-Leventhal, D., Handy, F., \& Cnaan, R. (2009). Volunteering among Israeli students: A cross-national comparison. Bitachon Sotziali, 79, 141-163.

Johnson, M. K., Beebe, T., Mortimer, J. T., \& Snyder, M. (1998). Volunteerism in adolescence: A process perspective. Journal of Research on Adolescence, 8(3), 309-332. Available at: http://dx.doi.org/10.1207/s15327795jra0803_2.

Kalekin-Fishman, D. (2018). Is there room for social activity as part of teacher training programs? Bita'on Machon Mofet, 61, 26-30.

Lampert, K. (2018). Is social-community intervention an important component of teacher training? Bita'on Machon Mofet, $61,3-7$.

Marullo, S., \& Edwards, B. (2000). From charity to justice: The potential of university-community collaboration for social change. American Behavioral Scientist, 43(5), 895-912. Available at: https://doi.org/10.1177/00027640021955540.

Maruyama, G., Furco, A., \& Song, W. (2017). Enhancing underrepresented students' success through participation in community engagement. In T. D. Mitchell, \& K. M. Soria (Eds.), Educating for citizenship and social justice: Practices for community engagement at research universities Cham (pp. 22 1-235). Palgrave Macmillan.

Monnickendam-Givon, Y., \& Blit-Cohen, E. (2012). Motives, understanding social policy, and characteristics of the activity of communal activists. Chevra Verevacha, 4(3), 513-534.

Peleg, C. (2000). The effect of working in the national student council on the personal development and social involvement of the elected representative Unpublished Master's Thesis. Derby University, Derby, England.

Sadan, E. (1997). Empowerment and community planning: Theory and practice of people-focused social solutions. Tel Aviv: Hakibbutz Hameuhad.

Sills, D. L. (1957). The volunteers: Means and ends in national organizations. Glencoe: The Free Press.

Thomson, A. M., Smith-Tolken, A. R., Naidoo, A. V., \& Bringle, R. G. (2010). Service-learning and community engagement: A comparison of three national contexts. Voluntas: International Journal of Voluntary and Nonprofit Organizations, 22(2), 214-237. Available at: https://doi.org/10.1007/s1 1266-010-9133-9.

Trajtenberg, M. (2013). Social involvement: Academia's third role $\neg-$ A booklet derived from the study day for academia and students' involvement in the community. Jerusalem: Council for Higher Education, Planning and Budgeting Committee, 7.

Volansky, A. (2005). Academy in a changing environment: Israel's higher education policy 1952-2004. Bnei Brak: Kav Adom, Hakibbutz Hameuhad. (Hebrew).

Weinberger, Y. (2016). Education in an age of uncertainty. Tel Aviv: Resling. (Hebrew). 